Biogeosciences, 10, 3917-3930, 2013

www.biogeosciences.net/10/3917/2013/

doi:10.5194/bg-10-3917-2013

(C) Author(s) 2013. CC Attribution 3.0 License.

\title{
Detection of large above-ground biomass variability in lowland forest ecosystems by airborne LiDAR
}

\author{
J. Jubanski ${ }^{1}$, U. Ballhorn ${ }^{1}$, K. Kronseder ${ }^{1}$, J Franke ${ }^{1}$, and F. Siegert ${ }^{1,2}$ \\ ${ }^{1}$ Remote Sensing Solutions GmbH, Isarstrasse 3, 82065 Baierbrunn, Germany \\ ${ }^{2}$ Biology Department II, GeoBio Center, Ludwig-Maximilians-University, Grosshaderner Strasse 2, 82152 \\ Planegg-Martinsried, Germany
}

Correspondence to: J. Jubanski (jubanski@rssgmbh.de)

Received: 1 August 2012 - Published in Biogeosciences Discuss.: 31 August 2012

Revised: 2 May 2013 - Accepted: 14 May 2013 - Published: 17 June 2013

\begin{abstract}
Quantification of tropical forest above-ground biomass (AGB) over large areas as input for Reduced Emissions from Deforestation and forest Degradation (REDD+) projects and climate change models is challenging. This is the first study which attempts to estimate AGB and its variability across large areas of tropical lowland forests in Central Kalimantan (Indonesia) through correlating airborne light detection and ranging (LiDAR) to forest inventory data. Two LiDAR height metrics were analysed, and regression models could be improved through the use of LiDAR point densities as input $\left(R^{2}=0.88 ; n=52\right)$. Surveying with a LiDAR point density per square metre of about 4 resulted in the best cost / benefit ratio. We estimated AGB for $600 \mathrm{~km}$ of LiDAR tracks and showed that there exists a considerable variability of up to $140 \%$ within the same forest type due to varying environmental conditions. Impact from logging operations and the associated AGB losses dating back more than 10 yr could be assessed by LiDAR but not by multispectral satellite imagery. Comparison with a Landsat classification for a 1 million ha study area where AGB values were based on site-specific field inventory data, regional literature estimates, and default values by the Intergovernmental Panel on Climate Change (IPCC) showed an overestimation of $43 \%, 102 \%$, and $137 \%$, respectively. The results show that AGB overestimation may lead to wrong greenhouse gas (GHG) emission estimates due to deforestation in climate models. For REDD+ projects this leads to inaccurate carbon stock estimates and consequently to significantly wrong REDD+ based compensation payments.
\end{abstract}

\section{Introduction}

In 2008 worldwide deforestation and forest degradation emissions are estimated as having accounting for about 6 $17 \%$ of the total anthropogenic carbon dioxide $\left(\mathrm{CO}_{2}\right)$ emissions (Van der Werf et al., 2009). In the period of 1990 to 2005 about 13 million ha of tropical forest were deforested annually, and with $0.98 \%$ South and Southeast Asia had one of the highest annual deforestation rates between 2000 and 2005 (FAO, 2006). Human economic activities such as the establishment of industrial timber estates and large-scale oil palm plantations, legal and illegal logging, and shifting cultivation are the main drivers of deforestation and forest degradation in this region (Hansen et al., 2009; Langner et al., 2007; Langner and Siegert, 2009; Rieley and Page, 2005; Siegert et al., 2001). One important measure of the United Nations Framework Convention on Climate Change (UNFCCC) to curb greenhouse gas (GHG) emissions from this sector is the Reduced Emissions from Deforestation and forest Degradation (REDD+) programme. Inaccurate estimates of GHG emission reductions can lead to misleading carbon credits that are not covered by the specific REDD+. Typically in tropical forests the main carbon pool is the aboveground biomass (AGB) (Chave et al., 2005; FAO, 1997; Gibbs et al., 2007). $\mathrm{CO}_{2}$ emissions from deforestation and forest degradation are estimated through the change in AGB, generally assessed as area of forest lost or degraded annually. AGB loss and associated $\mathrm{CO}_{2}$ emissions resulting from forest degradation by logging and fire are difficult to assess and monitor because their impacts may vary significantly. Detection of degradation is also important as degraded and 
regrowing will constitute the majority of remnant tropical forests (Putz, 2012). The most accurate method of AGB estimation is based on forest inventories where field measurements are extrapolated to AGB values through allometric equations (Chave et al., 2005; FAO, 1997). Although this approach provides precise AGB estimations, the biotic and structural complexity of tropical ecosystems make forest inventories difficult, time consuming, and expensive: generic relationships may not fit to specific areas, growth conditions may vary greatly within a specific forest ecosystem, and producing regionally and globally consistent results is challenging (Chave et al., 2005; Gibbs et al., 2007). Further, there is considerable uncertainty about the spatial variability of AGB in different tropical forest types and the impact of logging and fire on AGB stock. AGB can also be estimated by remote sensing technologies, but no such instrument can measure AGB directly; therefore in situ data collection is always necessary (Drake et al., 2003; Rosenqvist et al., 2003). The size of the area and the quality of the remote sensing data have major influence on the accuracy of the output. For global AGB and carbon stock estimation, moderateto coarse-resolution remote sensing data (e.g. MODIS) is typically used, and at a national or regional scale mediumresolution multispectral imagery or SAR data (Baccini et al., 2012; Englhart et al., 2011; Ryan et al., 2012; Saatchi et al., 2011).

Tropical peat forest ecosystems are one of the largest sinks of carbon. With $88.6 \mathrm{Gt}$ tropical peatlands are one of the largest near-surface pools of terrestrial organic carbon (IPCC, 2007; Page and Rieley, 1998; Page et al., 2010; Sorensen, 1993). In Indonesia peat accumulates over thousands of years and typically develops convex-form peat domes up to $20 \mathrm{~m}$ thick covered by peat swamp forest (Anderson, 1983; Page et al., 2004; Rieley et al., 1996; Rieley and Page, 2005). Due to high deforestation rates and emissions from peat by recurrent fires and drainage, which is especially observed in the coastal lowland areas of Sumatra and Kalimantan, Indonesia is among the largest $\mathrm{CO}_{2}$ emitters worldwide (Ballhorn et al., 2009; Hooijer at al., 2010; Page et al., 2002).

The main goal of this study was to estimate AGB and to investigate its spatial variability due to tree growth conditions and human impacts along several hundred kilometres of transects in lowland forest ecosystems in the Indonesian province of Central Kalimantan using small-footprint light detection and ranging (LiDAR). Central Kalimantan comprises a landscape of extensive lowlands with waterlogged peat swamp and lowland dipterocarp forests growing on dry mineral soils. Large-scale logging and peatland drainage have resulted in recurrent severe wildfire episodes that have destroyed large tracts of these ecosystems and led to huge $\mathrm{CO}_{2}$ emissions in the past (Ballhorn et al., 2009; Rieley and Page, 2005). Airborne LiDAR is a powerful technique for biomass quantification and monitoring because it provides information on the forest structure and has been successfully used to derive for- est AGB at different scales from single trees (Popescu, 2007; Zhao et al., 2009) to large contiguous forest stands (Asner et al., 2009a; Asner et al., 2010; Lefsky et al., 2002; Lefsky et al., 2005; Means et al., 1999). Asner et al. (2010) were successful in correlating small-footprint airborne LiDAR to AGB in a tropical lowland forest in Peru. The approach presented in our study on deriving AGB values from airborne LiDAR data follows guidelines proposed by Asner et al. (2010). However, no studies have yet investigated the AGB and its variability across large transects in tropical dipterocarp forests.

Especially for the tropical peat swamp forests of Indonesia, there is an urgent need to fill knowledge gaps regarding AGB values due to different reasons: (i) it is necessary to verify whether the approach on deriving AGB estimates from airborne LiDAR data is applicable to specific forest ecosystems in Indonesia; (ii) as Indonesia is one of the world's biggest emitters of carbon (Ballhorn et al., 2009; Hooijer et al., 2010; Page et al., 2002), it has high potential to negatively influence the global climate if its peatlands are further drained and burned at current rates; (iii) few field measurements considering AGB are available to date as most peatlands in Indonesia are highly inaccessible; (iv) the growing demand for palm oil, due to the biofuel boom, is a serious threat to these ecosystems, since peatlands are one of the only undeveloped and uninhabited near-coastal areas in Indonesia; (v) the number of REDD initiatives on peat forests in Indonesia is high (more than 40), and the only certified REDD project under the Voluntary Carbon Standard (VCS) to date in Indonesia is located on a peat swamp forest; (vi) REDD projects require a basic methodology on how to most accurately estimate AGB; and (vii) global climate models will need more reliable data on AGB.

\section{Materials and methods}

\subsection{Acquisition and processing of airborne LiDAR data}

From 5 to 10 August 2007 airborne LiDAR data were acquired in a flight campaign by Kalteng Consultants and Milan Geoservice GmbH (Fig. 1). Small-footprint fullwaveform LiDAR data covering an area of 33178 ha along a series of transects (length of approximately $600 \mathrm{~km}$ ) were recorded with a Riegl LMS-Q560 Airborne Laser Scanner from a flight altitude of approximately $500 \mathrm{~m}$ above ground and a scan angle of $\pm 30^{\circ}$ (swath width approx. $500 \mathrm{~m}$ ). The instrument had a pulse rate of up to 100000 pulses per second, a footprint diameter of $0.25 \mathrm{~m}$, and a wavelength of $1.5 \mu \mathrm{m}$ (near infrared). This survey configuration resulted in a nominal point density of $1.4 \mathrm{pt} \mathrm{m}^{-2}$ (average from the final point cloud per square metre). Under laboratory conditions this system allows height measurements of up to $\pm 0.02 \mathrm{~m}$. The acquired data set has an absolute vertical accuracy of $\pm 0.15 \mathrm{~m}$ and horizontal accuracy of $\pm 0.50 \mathrm{~m}$ root 

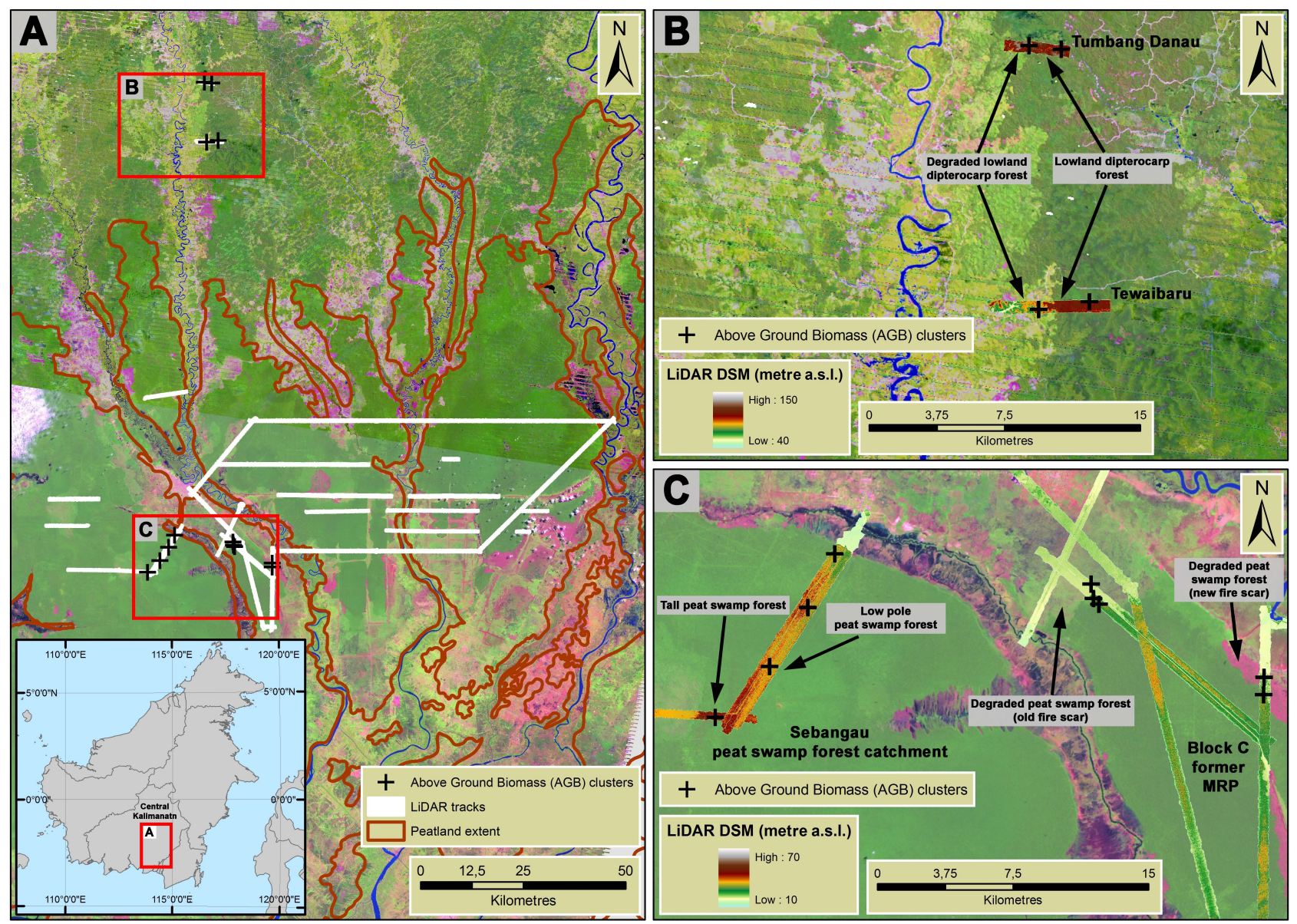

Fig. 1. Location of the LiDAR tracks and above-ground biomass (AGB) clusters (see Methods) ( 0.13 ha, indicated by black + ) in Central Kalimantan, Indonesia, superimposed on a Landsat image (ETM+ 118-61, 2009-05-22 and ETM+ 118-62, 2007-08-05; bands 5-4-3; and both scenes were gap filled). The red rectangles show the location of (A), (B), and (C). In (B) and (C) also the LiDAR-derived digital surface models (DSM) are shown.

mean square error (RMSE). The survey was conducted in the middle of the dry season (5 to 10 August) to avoid problems related to standing water. Field observations and data from an extensive network of water table measurement locations in the area, installed for several years, showed that the peat surface is dry during this period and no standing water occurs in the surveyed area (Jaenicke et al., 2011).

The point clouds formed by the waveform decompositions were further filtered to generate the DTMs. In this study, the filtering was the separation between ground and off-ground LiDAR points. The filtering approach applied was the hierarchic robust filtering (Pfeifer et al., 2001), and the method used to interpolate the DTMs (1 $\mathrm{m}$ resolution) the linear adaptable prediction interpolation. Both solutions are implemented within the Inpho software package. Hierarchic robust filtering is comparable to a hierarchical setup using image pyramids. The algorithm is based on linear prediction with individual accuracies for each LiDAR point and works iteratively. In the first step, all points are used to estimate the covariance function of the terrain. The first surface is computed with equal weights for all points and runs in an averaging way between ground and vegetation points. After the first model deviation, the filter values are computed and the weight of the points is altered according to the weight function. If a point is given a low weight, it will have lower influence on the run of the surface in the next iteration. The method runs iteratively a trend surface, followed by prediction, so that initially gross errors are eliminated, and then a refined filter is run. The results of the filtering were visually inspected and remaining outliers were removed interactively. The theoretical basis of the linear adaptable prediction, to describe the terrain surface, is presented in detail in various scientific publications (Kraus, 1998; Assmus, 1975; Wild, 1983). This method corresponds to the statistical estimation method Kriging, often applied in geosciences (Kraus, 1998). 

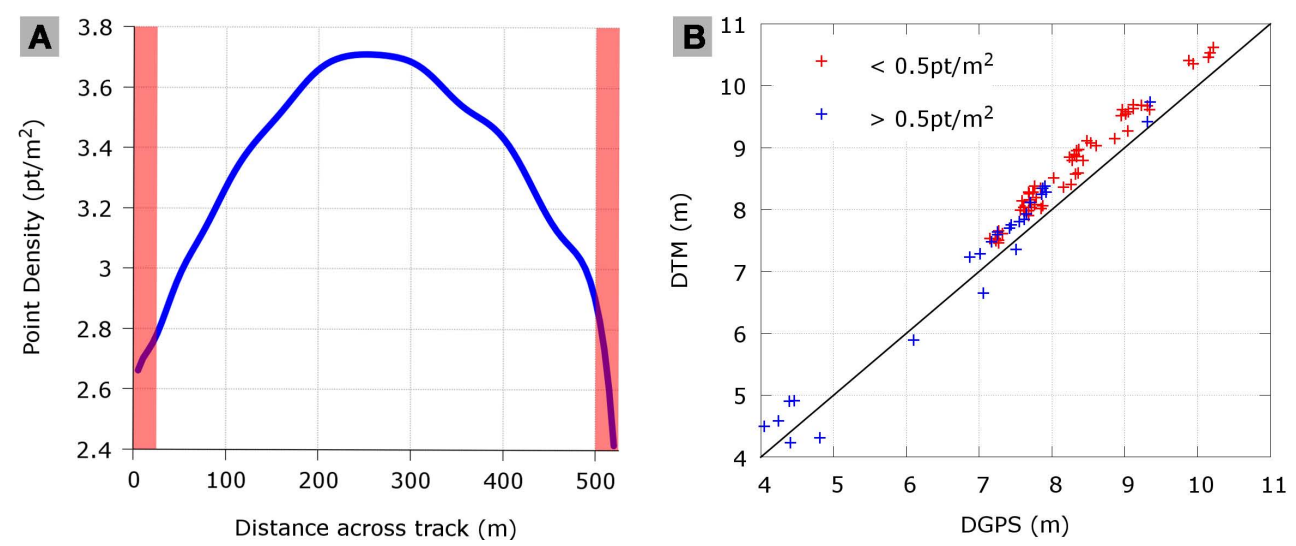

Fig. 2. (A) Typical across-track point density profile (blue). The red bars show the $25 \mathrm{~m}$ swath eliminated from the analysis. (B) DTM accuracy assessment. Points within areas with a point density lower than $0.5 \mathrm{pt} \mathrm{m}^{-2}$ (in red) show worse accuracies than points within higher point densities (blue).

In order to minimize problems in the strip borders (caused by LiDAR penetration and interception by vegetation) due to the large scan angle used $\left( \pm 30^{\circ}\right)$ we excluded $10 \%$ of the swath width ( $25 \mathrm{~m}$ of each side of the strip, see red bars in Fig. 2a) from the analysis. Figure 2a also shows the point density distribution of a typical across-track transect in our study area. We observed a reduction in point density of $25 \%$ to $40 \%$ from nadir to the edge of the swath caused by loss of signal strength in wider scan angles. Therefore, weighting the plots according to their point densities will indirectly take into account the scan geometry. A total of $80 \%$ of the field plots were collected within a swath of $\pm 15^{\circ}$. In addition we found that point density on the ground for scan angles greater than $15^{\circ}$ is high enough to separate ground points from vegetation. Additionally 88 differential GPS measurements in various locations along and across track were collected. DTM accuracy was $0.43 \mathrm{~m}$ RMSE (Fig. 2b).

\subsection{Forest inventory}

Forest inventory data were collected at three sites representative of lowland forest ecosystems from May to August 2008 where no changes were known to have occurred since the LiDAR survey (Fig. 1). The first site was located in the Sebangau peat swamp forest catchment, with 16 field inventory plots covering tall and low pole peat swamp forests. The second site was situated within Block $\mathrm{C}$ of the former Mega Rice Project (MRP), with 20 field inventory plots covering diverse degradation stages of peat swamp forest. The third study site was located in Tumbang Danau and Tewaibaru, with 16 field plots covering logged and unlogged lowland dipterocarp forests. Figure 4 shows 4 representative plots where canopy cover, tree height and canopy structure can be observed. The location of the plots were chosen on the basis of an extensive database of aerial photos, multispectral and SAR satellite imagery (such as RapidEye, Landsat, ALOS, ENVISAT, and TerraSAR-X), land cover maps de- rived from this imagery, accessibility and representativeness of the different environmental and ecological conditions, and that they lie within the LiDAR point clouds. In the field the plots were located with a GPS device (GPSmap60CSx, Garmin) which had an average horizontal accuracy of 5$10 \mathrm{~m}$ if measurements were averaged over $10 \mathrm{~min}$. This uncertainty can affect the final AGB modelling, but precise geodetic measurements within peat swamp forest are almost impracticable. Four nested plots of one cluster build the corners of a $50 \mathrm{~m} \times 50 \mathrm{~m}$ square. For convenience and due to limited resources, the minimum DBH threshold was set up at $7 \mathrm{~cm}$. The nested plot method is based on three circular plots with different sizes (Pearson et al., 2005). In each of the three circular plots, trees with a certain DBH range were recorded: 7 to $20 \mathrm{~cm}$ ( $4 \mathrm{~m}$ radius), 20 to $50 \mathrm{~cm}$ ( $14 \mathrm{~m}$ radius), and greater than $50 \mathrm{~cm}$ ( $20 \mathrm{~m}$ radius). The sum of the measured parameters of the two smaller nests was multiplied by an expansion factor in order to get the values for the $20 \mathrm{~m}$ radius inventory plot ( $0.13 \mathrm{ha}$ ). Local species name, tree height and DBH were recorded. Local tree names were translated to the corresponding Latin names through using local expert knowledge, tropical tree database provided by the World Agroforestry Centre (http://www.worldagroforestrycentre. org/Sea/Products/AFDbases/WD/Index.htm) and Chudnoff (1984), and data from a local herbarium at the Centre for International Co-operation in Management of Tropical Peatland (CIMTROP) in Palangka Raya. Also the species-specific wood densities were derived from the abovedescribed databases and from the Intergovernmental Panel on Climate Change (IPCC, 2006). Some local names, notably among dipterocarps, could not be related to a particular species. For these trees, an average wood density of $0.57 \mathrm{t} \mathrm{m}^{-3}$ was applied (FAO, 1997). Finally, the AGB values were calculated using an allometric equation for moist tropical forests from Chave et al. (2005). Two models are proposed by them for moist tropical forests, one which includes 

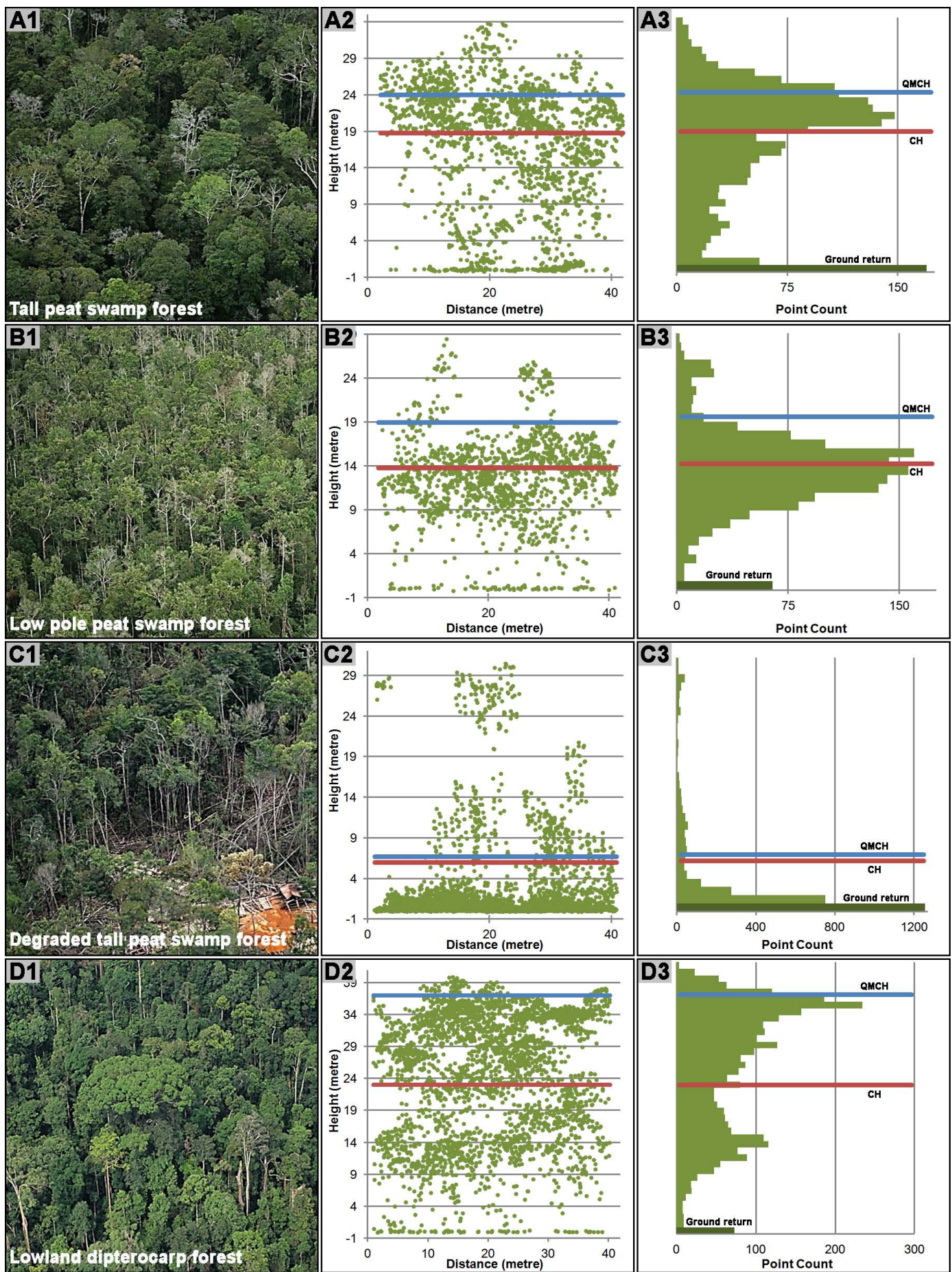

Fig. 3. Sample data set for each of the four investigated forest types. (A1) to (A3) show tall peat swamp forest $\left(\mathrm{AGB}=57.61 \mathrm{t} 0.13 \mathrm{ha}{ }^{-1}\right.$; LiDAR point density $=1.5 \mathrm{pt} \mathrm{m}^{-2}$; centroid height $(\mathrm{CH})=18.7 \mathrm{~m}$; quadratic mean canopy profile height $\left.(\mathrm{QMCH})=24.0 \mathrm{~m}\right)$. Note that $\mathrm{CH}$ and $\mathrm{QMCH}$ are in the upper canopy of the forest. (B1) to (B2) show low pole peat swamp forest (AGB $=19.12 \mathrm{t} 0.13 \mathrm{ha}{ }^{-1}$; $\mathrm{LiDAR}_{\mathrm{BD}}$ point density $\left.=1.1 \mathrm{pt} \mathrm{m}^{-2} ; \mathrm{CH}=13.7 \mathrm{~m} ; \mathrm{QMCH}=18.9 \mathrm{~m}\right)$. $(\mathbf{B 3})$ shows the forest structure (a small peak at about $24 \mathrm{~m}$ representing emergent trees and a large peak at about $14 \mathrm{~m}$ representing the main canopy layer). (C1) to (C3) show logged tall peat swamp forest (AGB $=5.05 \mathrm{t}$ $0.13 \mathrm{ha}^{-1}$; point density $\left.=2.9 \mathrm{pt} \mathrm{m}^{-2} ; \mathrm{CH}=5.8 \mathrm{~m} ; \mathrm{QMCH}=6.2 \mathrm{~m}\right)$. The small peak in $(\mathbf{C 2})$ at about $26 \mathrm{~m}$ height indicates remaining tall trees. (C3) clearly shows the predominant ground return. $\mathrm{CH}$ and $\mathrm{QMCH}$ are located at similar heights. (D1) to (D3) show lowland dipterocarp forest $\left(\mathrm{AGB}=108.20 \mathrm{t} 0.13 \mathrm{ha}^{-1} ; \mathrm{LiDAR}\right.$ point density $=2.3 \mathrm{pt} \mathrm{m}^{-2} ; \mathrm{CH}=25.3 \mathrm{~m}$; QMCH $\left.=35.3 \mathrm{~m}\right)$. The two peaks in $(\mathbf{D 3})$ (at about $14 \mathrm{~m}$ and $34 \mathrm{~m}$ ) indicate a complex multilayered forest structure. 
tree height, DBH, and wood density, while the other includes DBH and wood density, but not tree height. It was decided to use the second model excluding tree height as tree height measurements in the field were highly inaccurate and often impossible to measure due to the dense and tall forest canopy. The AGB value within the plots was calculated for each tree individually, summed up and divided by the surface sample to be expressed in $\mathrm{Mg} \mathrm{ha}^{-1}$.

\subsection{Generation of the regression models}

The first step for the generation of the regression models was the creation of a height histogram for every field plot using the LiDAR data. In order to achieve this, all points within each plot area were normalized to the ground using the DTM as reference. After that, given a pre-defined height interval of $1 \mathrm{~m}$ (or bin size), the number of points within the given intervals were stored in the form of a histogram. In order to correlate the AGB field observations with the LiDAR metrics, two parameters derived from the height histograms were used. The first, developed for this work, is based on centroid height $(\mathrm{CH})$ of the histogram. The second one correlates the AGB with the quadratic mean canopy profile height (QMCH) (Asner et al., 2010; Lefsky, 1999). The first bin of each plot was considered ground return and therefore eliminated from further processing.

One important parameter in LiDAR surveys is the point density. The acquisition of high point densities is expensive, because it requires the most recent equipment and a slow and low-flying aircraft. The real point density can strongly vary across the surveyed area mainly due to stripe overlapping, flight velocity, height variation, target reflectance, and return quality degradation caused by smoke or water vapour in the atmosphere. In order to account for these factors within the regression models, the point density was used for each plot as a weighting factor. Since the point density directly affects the quality of the height histogram, this also directly affects the derived metrics (i.e. the $\mathrm{CH}$ and $\mathrm{QMCH}$ ). Usually, the regression models applied for AGB estimations assume AGB as a dependent variable and the LiDAR metrics as independent. In this study, this order was changed because the leastsquares solution chosen permitted only weighting the dependent variables, which are treated as observations with known weights - the point densities. For both studied metrics $(\mathrm{CH}$ and $\mathrm{QMCH}$ ) the regression models were derived with and without point density weighted adjustment. After the regression processing, the obtained parameters were transformed in order to obtain an equation that directly determines the AGB based on the LiDAR metrics. In order to verify the influence of point density on the AGB estimation accuracy, an error propagation analysis was performed (see Sect. 2.4).

In order to evaluate the AGB variability, we estimated AGB in a grid with $5 \mathrm{~m}$ resolution to $600 \mathrm{~km}$ (33 178 ha) of LiDAR tracks covering pristine and degraded forest in Central Kalimantan. For each cell, we computed the height his- tograms within a radius of $20 \mathrm{~m}$ (the same radius as the field plots). The chosen regression model was the $\mathrm{CH}$ due to its higher correlation coefficient and lower RMSE.

\subsection{Error propagation analysis}

The regression model used in this work correlates the AGB with the LiDAR metrics (LM) through a power function:

$\mathrm{AGB}=a \cdot \mathrm{LM}^{b}$

We applied covariance propagation (Breipohl, 1970) to the mathematical model shown in Eq. 1, considering LM as a variable and ignoring the variances and covariances of a and b. The AGB variance $\left(\sigma_{\mathrm{AGB}}^{2}\right)$ assumes the following form:

$\sigma_{\mathrm{AGB}}^{2}=\left(a \cdot b \cdot \mathrm{LM}^{b-1}\right)^{2} \cdot \sigma_{\mathrm{LM}}^{2} \cdot$

As we assume that the quality of a plot (weight) grows with its point density $(\rho)$, we determine the AGB standard deviation $\left(\sigma_{\mathrm{AGB}}\right)$ :

$\sigma_{\mathrm{AGB}}=\left(a \cdot b \cdot \mathrm{LM}^{b-1}\right) \cdot 0 \rho^{-0.5}$.

Equation (2) was applied to the $\mathrm{CH}$ and $\mathrm{QMCH}$ models derived in this work in order to evaluate the influence of the parameters LM and $\rho$ in the accuracy of the AGB estimation. Results are shown in Fig. 4 and Sect. 3.

\subsection{Comparison between optical remote sensing and LiDAR for AGB estimation}

Prior to the image classification, the Landsat imagery (ETM+ 118-62, 2007-08-05) was atmospherically corrected using ATCOR (Richter, 1997). The land cover classification for the 1 million ha study area was implemented using an object-based image analysis approach (software eCognition, Trimble GeoSpatial, Munich, Germany). In a first step, this approach generates image objects from spatially adjacent pixels with similar spectral values, which are then classified by a user-defined rule set. In order to differentiate primary and secondary forests, a pixel-based spectral mixture analysis (SMA) was applied to the data. SMA have a high potential to derive forest degradation from remote sensing data (Asner et al., 2009b; Matricardi et al., 2010; Souza at al., 2005). A linear SMA assumes that each pixel spectrum is a linear combination of a finite number of endmembers (Adams et al., 1986). The results of a SMA - i.e. scaled sub-pixel fractions representing photosynthetically active vegetation, nonphotosynthetic vegetation (NPV), soil and shade - were used to derive disturbed forest areas. The final land cover classification had an overall accuracy of $89 \%$ with a Kappa coefficient of 0.88 .

Next the LiDAR AGB estimates for 28284 ha of the LiDAR tracks, covering pristine and degraded peat swamp forests, were quantitatively compared to AGB estimates based on a Landsat classification. The AGB values of the 

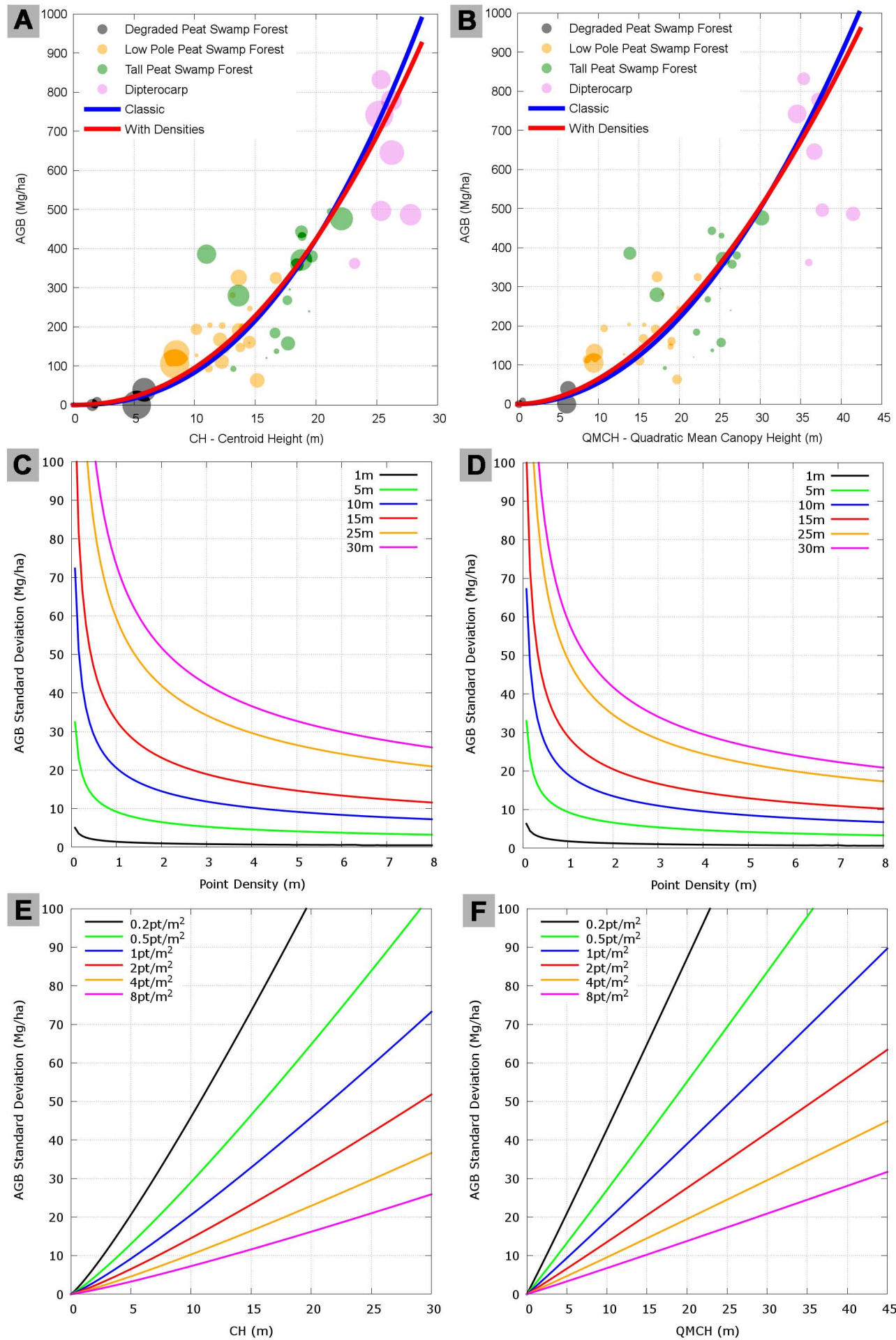

Fig. 4. Biomass regression and error propagation analysis results. (A) In red the centroid height (CH)-based regression model with LiDAR point density weighting (AGB $=0.0865 \times \mathrm{CH}^{2.1564} ; R^{2}=0.88$; root mean square error (RMSE) $= \pm 13.79 \mathrm{t} 0.13 \mathrm{ha}^{-1}$; predictive power of the regression $(\mathrm{PPR})= \pm 14.98 \mathrm{t} 0.13 \mathrm{ha}^{-1}$ ) and in blue without weighting $\left(\mathrm{AGB}=0.0484 \times \mathrm{CH}^{2.3494} ; R^{2}=0.79 ; \mathrm{RMSE}= \pm 16.06 \mathrm{t}\right.$

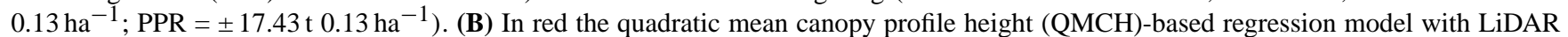
point density weighting $\left(\mathrm{AGB}=0.1150 \times \mathrm{QMCH}^{2.0277} ; R^{2}=0.84\right)$ and in blue without weighting $\left(\mathrm{AGB}=0.0660 \times \mathrm{QMCH}^{1.8656} ; R^{2}=\right.$ 0.76). The circle size in (A) and (B) represents the point densities (the smallest about $0.2 \mathrm{pt} \mathrm{m}^{-2}$ and the biggest about $3.5 \mathrm{pt} \mathrm{m}^{-2}$ ). (C) and (D) show standard deviation estimation curves for $\mathrm{CH}$ and $\mathrm{QMCH}$ due to variation of the point density for diverse values $(1 \mathrm{~m}, 5 \mathrm{~m}$, $10 \mathrm{~m}, 15 \mathrm{~m}, 20 \mathrm{~m}$ and $30 \mathrm{~m}$ ). (E) and (F) show the standard deviation estimation curves for CH- and QMCH-based regression models due to variation of $\mathrm{CH}$ and $\mathrm{QMCH}$ for 6 different point densities $\left(0.2,0.5,1,2,4\right.$ and $\left.8 \mathrm{pt} \mathrm{m}^{-2}\right)$. 

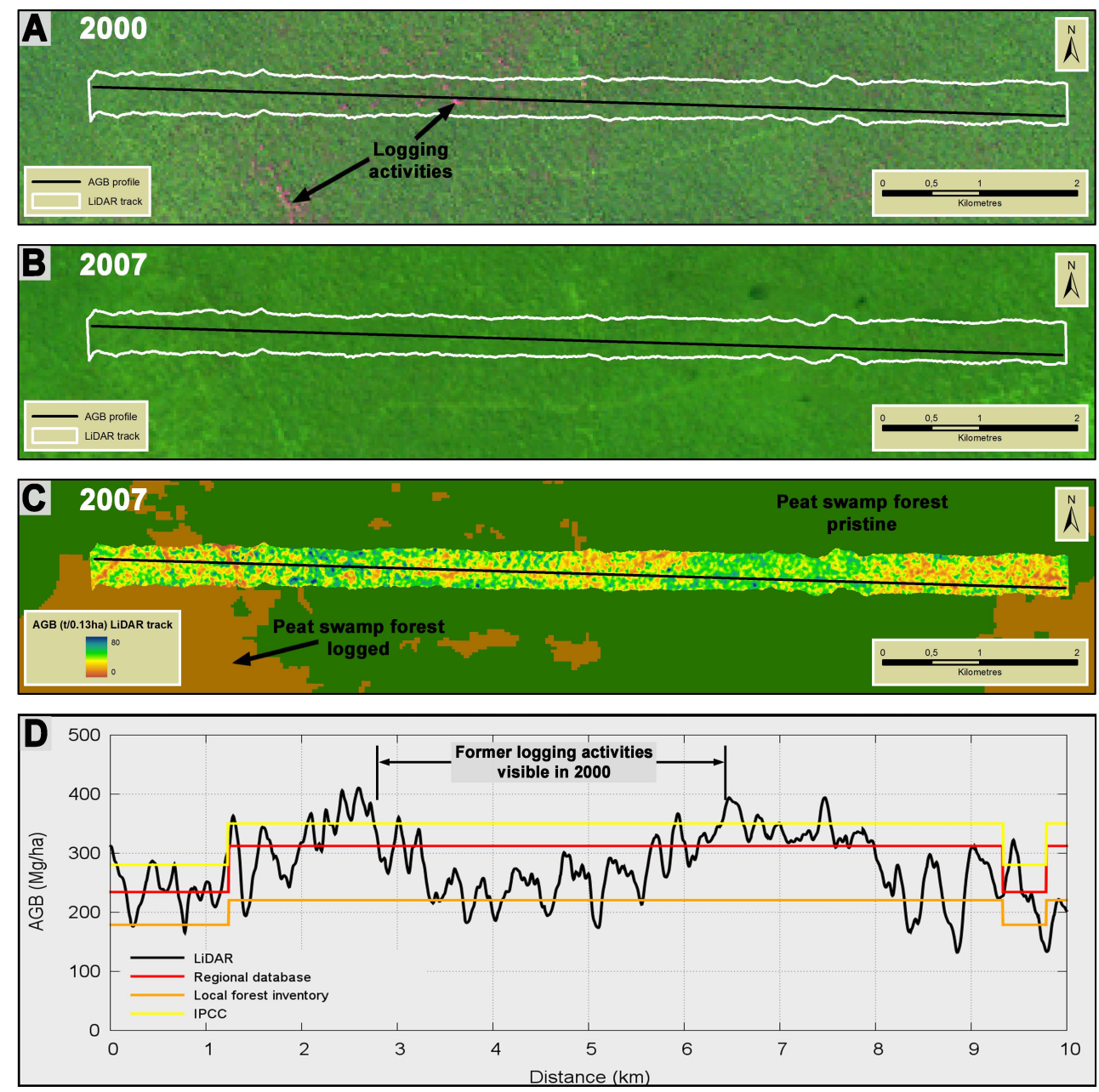

Fig. 5. AGB results shown for a LiDAR track covering 10km in the Sebangau peat swamp forest catchment. Location of this LiDAR track is shown in Fig. 6 (AGB profile 1). (A) Extent of the LiDAR track and the location of the AGB profile of (D) superimposed on a Landsat scene from the year 2000 (ETM+ 118-62, 2000-07-16; bands 5-4-3). Green represents forest cover, and logging activities are visible as pink dots near straight line features (logging railways). (B) Extent of the LiDAR track and the location of the AGB profile of (D) superimposed on a Landsat scene from the year 2007 (ETM+ 118-62, 2007-08-05; bands 5-4-3; gap filled). The logging activities are not visible anymore. (C) LiDAR AGB regression results superimposed on the Landsat classification (green = peat swamp forest pristine; brown = peat swamp forest logged). (D) AGB variability measured by LiDAR (black) and the corresponding AGB estimates attributed to the land cover types of the Landsat classification. Site-specific inventory data (field plots) = orange; regional literature estimates (regional database) = red; and IPCC default values $($ IPCC) $=$ yellow. Black arrows indicate the extent of the logging activities seen in (A).

land cover types were derived from site-specific field inventory data $(n=53)$, regional literature estimates (literature values for the Indo-Malayan archipelago), and IPCC default values (IPCC, 2006) and assigned to the land cover types classified in the satellite imagery, which is a method often used (Gibbs et al., 2007). Site-specific field inventory data represent Tier $2 / 3$, regional literature estimates Tier 2, and IPCC default values Tier 1 of the IPCC Guidelines for National Greenhouse Gas Inventories (IPCC, 2006). Higher tiers represent higher levels of precision and accuracy in AGB estimation (IPCC, 2006). Finally the average LiDAR AGB estimates within the LiDAR tracks for the land cover classes on peatlands were extrapolated to the 1 million ha study area and compared to the AGB results based on the site-specific field inventory data, regional literature estimates, and IPCC default values.

For the burned class it has to be noted that the Landsat classification also includes burned areas where regrowth already took place for more than 3 years. On the other hand, the field plots (but also the regional literature estimates and the IPCC default values) were collected in fire scars not older than 3 years. This explains the difference in AGB between the LiDAR estimates and the estimates based on the sitespecific field inventory data, regional literature estimates, and 

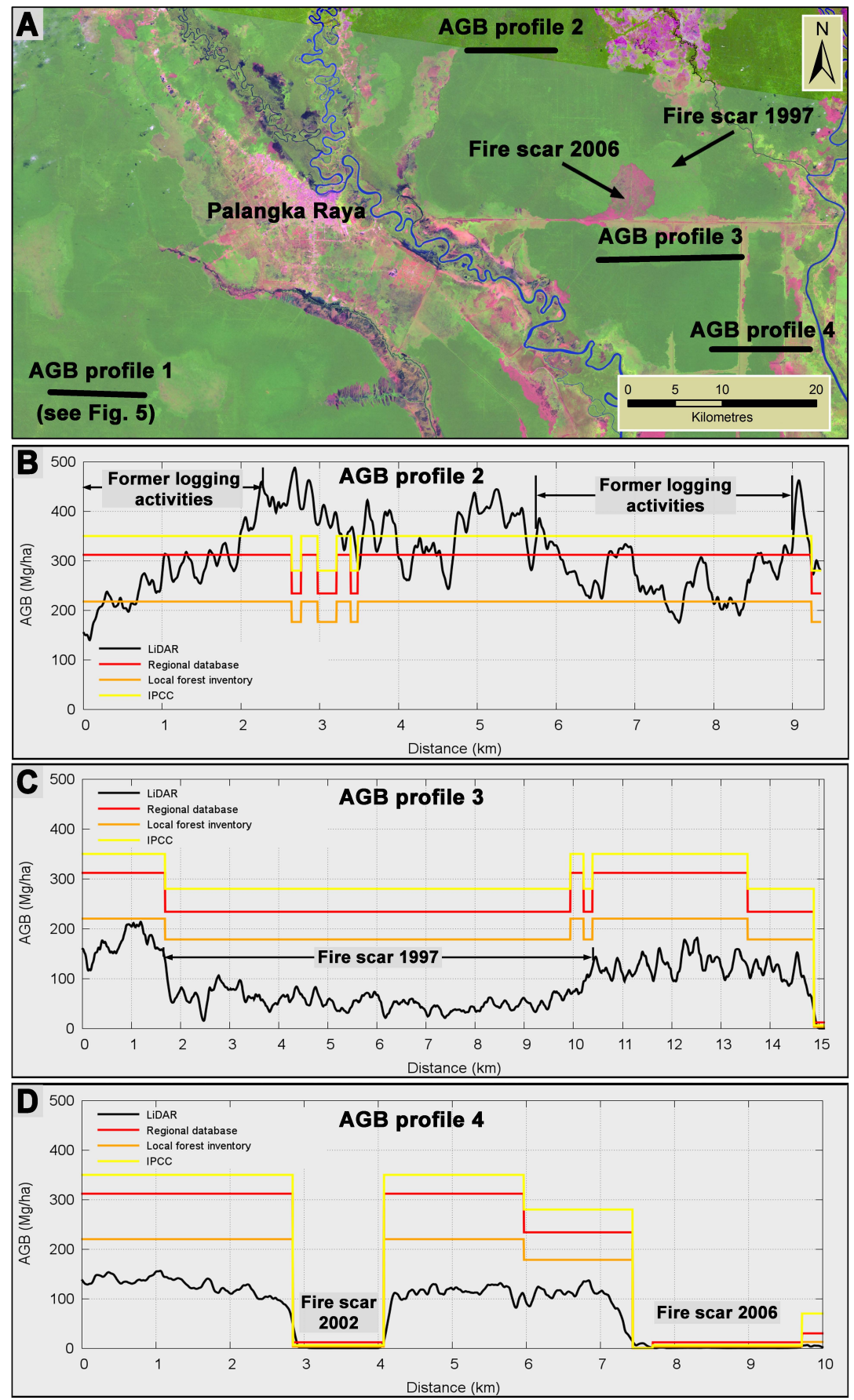

Fig. 6. Examples of different AGB profiles where LiDAR-based AGB estimates are compared to the AGB values attributed to the land cover classes from the Landsat classification on peatlands within the LiDAR stripes. Three different sources for AGB values were attributed to the land cover classes: site-specific field inventory data (field plots, orange), regional literature estimates (regional database, yellow), and IPCC default values (IPCC, red). AGB profile 1 is described in more detail in Fig. 3. (A) Location of the AGB profiles within the study area superimposed on Landsat imagery from the year 2007. (B) AGB profile $2(9.5 \mathrm{~km} \mathrm{long})$ covers two areas of former logging activities $(0.0-2.2 \mathrm{~km}$ and $5.9-9.0 \mathrm{~km})$ within a peat swamp forest. Here the AGB variability within the forest and the lower AGB values in the logging areas is visible in the LiDAR estimates but not in the Landsat-based estimates. (C) AGB profile 3 (15.2 km long) within a peat swamp forest covering a fire scar from the year $1997(1.8-10.4 \mathrm{~km})$. The Landsat-based AGB estimates are much higher than the LiDAR estimates. Also the LiDAR AGB estimates give an idea on the AGB variability which the Landsat-based estimates are not able to give. (D) AGB profile 4 (10 km long) within a peat swamp forest covering one fire scar from the year $2002(2.9-4.1 \mathrm{~km})$ and another fire scar from the year 2006 $(7.5-10.0 \mathrm{~km})$. Here also the Landsat-based AGB estimates for peat swamp forest are much higher than the LiDAR estimates. 
IPCC default values (Tables 1 and 2). As both area and AGB of this class are small, this does not have a big impact on the overall results (Tables 1 and 2).

\section{Results}

The LiDAR point clouds were analysed using both techniques presented in section $2.3(\mathrm{CH}$ and $\mathrm{QMCH})$. These parameters were correlated to field-estimated AGB values $(0.13 \mathrm{ha})$ in order to establish robust biomass estimation models. The biomass estimation model using $\mathrm{CH}$ as input was applied to $600 \mathrm{~km}$ (33 178 ha) of LiDAR tracks covering pristine and degraded forest types in Central Kalimantan.

Four main forest types - tall peat swamp forest, low pole peat swamp forest, degraded forest (logged or burned) and lowland dipterocarp forest - were investigated. Fig. 3 shows four typical field plots, their LiDAR height profiles with vegetation heights, and the derived LiDAR height histograms, which illustrate the structural differences between the different forest types and the impact of degradation.

Figure 4a shows the results for the regression using the $\mathrm{CH}$ as input. It is possible to observe the AGB variation among the different forest types (grey represents degraded forests, orange peat swamp forest and green dipterocarp forest). A high correlation coefficient $\left(R^{2}=0.88\right.$; RMSE $= \pm 13.79 \mathrm{t}$ $\left.0.13 \mathrm{ha}^{-1} ; \mathrm{PPR}= \pm 14.98 \mathrm{t} 0.13 \mathrm{ha}^{-1}\right)$ was obtained when the LiDAR point densities per square metre $\left(\mathrm{pt} \mathrm{m}^{-2}\right)$ were treated as weight during the regression. The derived coefficient of determination is comparable with those reported in other studies of tropical forests (Asner et al., 2009a; Asner et al., 2010; Drake et al., 2002). Also for the QMCH a high correlation was obtained $\left(R^{2}=0.84\right)$ when applying the $\mathrm{Li}$ DAR point density as weight (Fig. 4b). In both cases, the use of the LiDAR point densities as weight improved the regression models. This also shows that, in this case, the $\mathrm{CH}$ is a better parameter for AGB estimations.

The costs of LiDAR surveying depend on the point density. To assess the influence of the LiDAR point density on the quality of the AGB estimation, a rigorous error propagation analysis was performed (see Sect. 2.4). The results (Fig. 4c and d) suggest that LiDAR surveying with more than $4 \mathrm{pt} \mathrm{m}^{-2}$ does not significantly improve the AGB regression models. On the other hand, surveying with less than $1 \mathrm{pt} \mathrm{m}^{-2}$ may lead to significant inaccuracies. Figure $4 \mathrm{e}$ and $\mathrm{f}$ show that the standard deviations grow with the LiDAR metric $(\mathrm{CH}$ or $\mathrm{QMCH})$. Higher AGB values have higher standard deviations (uncertainties). For higher point densities, the standard deviation grows slower. For a typical tall peat swamp forest plot (Fig. 1a, with a $\mathrm{CH}$ of $18.7 \mathrm{~m}$ ), the standard deviation for a point density of $2 \mathrm{pt} \mathrm{m}^{-2}$ is $29 \mathrm{Mg} \mathrm{ha}^{-1}$, while with $4 \mathrm{pt} \mathrm{m}^{-2}$ this value is $21 \mathrm{Mg} \mathrm{ha}^{-1}$, a difference of about $30 \%$. This suggests that surveying with a point density of about $4 \mathrm{pt} \mathrm{m}^{-2}$ is a good trade-off between cost and accuracy.
To validate the proposed AGB estimation, we determined the predictive power of the regression (PPR) as proposed by Asner et al. (2010). A total of 5000 iterations were performed randomly leaving $10 \%$ of the plots out of the regression as control. The RMSE after this iterative process was about $8 \mathrm{tha}^{-1}$ higher than the RMSE determined using all plots in the regression. These results are similar to the ones presented by Asner et al. (2010).

Next the spatial variability of AGB along the $600 \mathrm{~km} \mathrm{Li}-$ DAR tracks was analysed. Through applying the $\mathrm{CH}$-based regression model, it was possible to illustrate AGB variability linked to local soil properties and water-logged conditions and the impact of previous logging operation and fire with high spatial resolution. Figure 5 shows a $10 \mathrm{~km}$ long (408 ha) LiDAR transect covering pristine and logged peat swamp forest (location of this transect is shown in Fig. 1). Figure 5a shows a Landsat scene acquired in the year 2000 where forests appear in green and logging impact in pink colours. Historical Landsat imagery suggests that logging occurred here in the year 1997. After 1998 all logging operation ceased. In the 2007 Landsat image past logging activity was no longer visible (Fig. 5b), but it is still detectable in the LiDAR AGB profile shown in Fig. 5d (black, black arrows). There is an AGB variation of up to $150 \%$ in logged and pristine peat swamp forest $\left(150-380 \mathrm{tha}^{-1}\right)$ (Fig. 5d). The AGB is approximately $35 \%$ lower than in adjacent areas with little or no logging impact although there has been 10 years of forest regrowth. LiDAR AGB spatial profiles clearly show the ability of airborne LiDAR to assess AGB variability with high spatial resolution and also detect former logging activity which is no longer visible in recent multispectral satellite imagery (Fig. 5a, b, and d).

A standard method to estimate AGB is to assign AGB values to a land cover classification based on multispectral satellite imagery (indirect method) (Gibbs et al., 2007). In the case of the LiDAR track shown in Fig. 5, the Landsatbased classification only allows for the discrimination between two land cover classes, i.e. peat swamp forest pristine and logged. In Fig. 5c the LiDAR AGB estimates are superimposed on the Landsat-based land cover classification. Fig. 5d shows a comparison between AGB estimates from LiDAR (black), site-specific field inventory data (orange), regional literature estimates (yellow), and IPCC default values (red). From Fig. $5 c$ and $d$ it is clear that the spectral reflectance in Landsat imagery does not represent the spatial AGB heterogeneity. Thus, AGB losses by logging will be undetected or underestimated. In this study it leads to a serious overestimation of the AGB by the indirect method. Fig. 6 shows more examples of the observed AGB variability. In Fig. 6 a the location of these profiles within the study area is shown and superimposed on Landsat imagery acquired in the year 2007. Green colours indicate lowland dipterocarp forest, while pink and red colours indicate sparse vegetation. Fire scars from fires several years back in time appear in light green; recent fire scars from the year 2006 
Table 1. Above-ground biomass (AGB) comparison between the LiDAR-based estimations and AGB estimations where AGB values were based on site-specific field inventory data (field plots), regional literature estimates (literature), and IPCC default values (IPCC), according to land cover classes, derived from a Landsat (multispectral satellite) classification, for the peatlands within the LiDAR stripes of the 1 million ha study area $(\mathrm{Mt}=$ Megaton).

\begin{tabular}{|c|c|c|c|c|c|c|c|c|c|c|c|c|c|c|c|c|c|}
\hline \multicolumn{3}{|c|}{ Class } & \multicolumn{4}{|c|}{ Averaged AGB (t/0.13 ha) } & \multicolumn{8}{|c|}{ Total AGB $(\mathrm{Mt})$} & \multicolumn{3}{|c|}{ Difference $(\%)$} \\
\hline Name & Area (ha) & $\%$ & LiDAR & Field plots & Literature & IPCC & LiDAR & $\%$ & Field plots & $\%$ & Literature & $\%$ & IPCC & $\%$ & $\begin{array}{l}\text { LiDAR - } \\
\text { field plots }\end{array}$ & $\begin{array}{l}\text { LiDAR - } \\
\text { literature }\end{array}$ & $\begin{array}{c}\text { LiDAR - } \\
\text { IPCC }\end{array}$ \\
\hline $\begin{array}{l}\text { Peat swamp } \\
\text { forest pristine }\end{array}$ & 9724.53 & 36 & $\begin{array}{c}20.67 \\
( \pm 14.68)\end{array}$ & $\begin{array}{c}28.62 \\
( \pm 9.48)\end{array}$ & $\begin{array}{c}40.56 \\
( \pm 24.57)\end{array}$ & 45.50 & 1.546 & 65 & $\begin{array}{c}2.141 \\
( \pm 0.709)\end{array}$ & 62 & $\begin{array}{c}3.034 \\
( \pm 1.838)\end{array}$ & 63 & 3.404 & 61 & 38 & 96 & 120 \\
\hline $\begin{array}{l}\text { Peat swamp } \\
\text { forest logged }\end{array}$ & 7094.17 & 27 & $\begin{array}{c}13.78 \\
( \pm 12.12)\end{array}$ & $\begin{array}{c}23.20 \\
( \pm 9.53)\end{array}$ & $\begin{array}{c}30.42 \\
( \pm 24.57)\end{array}$ & 36.40 & 0.752 & 32 & $\begin{array}{c}1.266 \\
( \pm 0.520)\end{array}$ & 37 & $\begin{array}{c}1.660 \\
( \pm 1.341)\end{array}$ & 34 & 1.986 & 35 & 68 & 121 & 164 \\
\hline $\begin{array}{l}\text { Bushland/ } \\
\text { regrowth }\end{array}$ & 2828.97 & 11 & $\begin{array}{c}1.86 \\
( \pm 5.16)\end{array}$ & $\begin{array}{c}1.64 \\
( \pm 1.08)\end{array}$ & $\begin{array}{c}3.90 \\
( \pm 7.02)\end{array}$ & 9.10 & 0.040 & 2 & $\begin{array}{c}0.036 \\
( \pm 0.023)\end{array}$ & 1 & $\begin{array}{c}0.085 \\
( \pm 0.153)\end{array}$ & 2 & 0.198 & 4 & -12 & 110 & 390 \\
\hline $\begin{array}{l}\text { Grassland/ } \\
\text { fern }\end{array}$ & 5543.88 & 21 & $\begin{array}{c}0.33 \\
( \pm 2.09)\end{array}$ & $\begin{array}{c}0.43 \\
( \pm 1.35)\end{array}$ & $\begin{array}{c}1.56 \\
( \pm 1.75)\end{array}$ & 0.81 & 0.014 & 1 & $\begin{array}{c}0.019 \\
( \pm 0.058)\end{array}$ & 1 & $\begin{array}{c}0.067 \\
( \pm 0.074)\end{array}$ & 1 & 0.034 & 1 & 31 & 370 & 143 \\
\hline Burned & 1509.79 & 6 & $\begin{array}{c}1.36 \\
( \pm 3.50)\end{array}$ & $\begin{array}{c}0.09 \\
( \pm 1.09)\end{array}$ & 0.00 & 0.00 & 0.016 & 1 & $\begin{array}{c}0.001 \\
( \pm 0.013)\end{array}$ & 0 & 0.00 & 0 & 0.00 & 0 & -93 & -100 & -100 \\
\hline Total & 26701.34 & 100 & & & & & 2.369 & 100 & $\begin{array}{c}3.462 \\
( \pm 2.596)\end{array}$ & 100 & $\begin{array}{c}4.845 \\
( \pm 6.736)\end{array}$ & 100 & 5.622 & 100 & 46 & 105 & 137 \\
\hline
\end{tabular}

appear in red. AGB profile 2 in Fig. $6 \mathrm{~b}$ transects two areas of previous logging activity. The LiDAR data set indicates lower AGB values in logged areas which are not detectable in the Landsat-image- and the land-cover-based estimate. AGB profile 3 (Fig. 6c) transects a fire scar which was created during the severe fire disaster in 1997. Here the Landsat-based estimate is higher than the LiDAR estimate. Forest regrowth was much slower than expected and thus the AGB is overestimated. AGB profile 4 (Fig. 6d) covers peat swamp forest and two fire scars from different years (2002 in the west and 2006 in the east) located on a higher section of the elevated peat dome. The LiDAR AGB indicates significantly lower AGB values for the peat swamp forest than in other areas in the study site or than indicated by standard AGB values, most likely caused by unfavourable growth conditions. In all 4 profiles, the AGB values obtained by the indirect method (local forest inventory, regional database and IPCC) show significant over- and/or underestimations in comparison to the direct method obtained from LiDAR .

Table 1 presents the results of the comparison between the LiDAR AGB estimates for the LiDAR tracks; Table 2 presents the up-scaling of these estimates to the whole study area compared to other methods and standard AGB values. The variation of the LIDAR AGB estimates for different land cover classes (based on the Landsat classification) is noticeable here as well (Tables 1 and 2). For areas classified as peat swamp pristine forest, representing $36 \%$ of all LiDAR track area and constituting approximately $65 \%$ of the total estimated AGB, this variation can be up to $140 \%$ (Table 1). Furthermore, the LiDAR AGB estimates for this class are $38 \%, 96 \%$, and $120 \%$ lower than using values assigned to this class based on the site-specific field inventory data, regional literature estimates, and IPCC default values, respectively (Table 1). Similar relationships were found in other land cover classes, and therefore the direct LiDAR-based AGB estimate is in total $43 \%$ (site-specific field inventory data), $102 \%$ (regional literature estimates), $137 \%$ (IPCC default values) lower than the indirect method considering the 1 million ha study area (Table 2). This overestimation by other methods is higher than that shown by Asner et al. (2010), who observed a $33 \%$ lower regional LiDAR-based carbon estimate than by a default approach based on average IPCC (IPCC, 2006) carbon values assigned to biomes in the Peruvian Amazon.

\section{Discussion}

Our results confirm that the use of airborne LiDAR data is a very reliable solution for large-scale AGB and carbon stock estimation (Asner et al., 2009a; Asner et al., 2010; Lefsky et al., 2002; Lefsky et al., 2005; Means et al., 1999; Popescu, 2007; Zhao et al., 2009;). Despite its relatively high operation costs for large-scale mapping, this approach produces the most accurate estimates of forest carbon stocks in that it captures the natural spatial variability and previous impacts like logging. Global estimates based on low- and mediumresolution satellite data (Baccini et al., 2012; Saatchi et al., 2011) do not capture the local variability in forest AGB (natural and human caused) which is required for REDD+ project measuring, reporting, and verification (MRV) systems. A "benchmark" map of biomass carbon stock for the tropics, based on a combination of in situ inventory plots, satellite LiDAR data, and optical and microwave imagery $(1 \mathrm{~km}$ resolution), showed that especially for the peat forest areas of Central Kalimantan the uncertainty in biomass carbon stock estimates was very high ( $>45 \%)$ (Saatchi et al., 2011). This high uncertainty, the limited amount of in situ field measurements in Southeast Asian tropical forests (especially in tropical peat swamp forests), and the inability of high and medium multispectral resolution satellite instruments such as Landsat to quantify historic forest disturbance show the importance to derive more accurate AGB estimates 
Table 2. Above-ground biomass (AGB) comparison between the LiDAR-based estimations and AGB estimations where AGB values were based on site-specific field inventory data (field plots), regional literature estimates (literature), and IPCC default values (IPCC), according to land cover classes, derived from a Landsat (multispectral satellite) classification, for the peatlands for the whole 1 million ha study area (Mt = Megaton).

\begin{tabular}{|c|c|c|c|c|c|c|c|c|c|c|c|c|c|}
\hline \multicolumn{3}{|c|}{ Class } & \multicolumn{8}{|c|}{ Total AGB $(\mathrm{Mt})$} & \multicolumn{3}{|c|}{ Difference $(\%)$} \\
\hline Name & Area (ha) & $\%$ & LiDAR & $\%$ & Field plots & $\%$ & Literature & $\%$ & IPCC & $\%$ & $\begin{array}{l}\text { LiDAR - } \\
\text { field plots }\end{array}$ & $\begin{array}{l}\text { LiDAR - } \\
\text { literature }\end{array}$ & $\begin{array}{l}\text { LiDAR - } \\
\text { IPCC }\end{array}$ \\
\hline $\begin{array}{l}\text { Peat swamp } \\
\text { forest pristine }\end{array}$ & 351588.32 & 39 & $\begin{array}{c}55.912 \\
( \pm 39.702)\end{array}$ & 71 & $\begin{array}{c}77.408 \\
( \pm 25.639)\end{array}$ & 68 & $\begin{array}{c}109.696 \\
( \pm 66.450)\end{array}$ & 69 & 123.056 & 66 & 38 & 96 & 120 \\
\hline $\begin{array}{l}\text { Peat swamp } \\
\text { forest logged }\end{array}$ & 186130.60 & 20 & $\begin{array}{c}19.725 \\
( \pm 17.353)\end{array}$ & 25 & $\begin{array}{c}33.201 \\
( \pm 13.645)\end{array}$ & 29 & $\begin{array}{c}43.555 \\
( \pm 35.179)\end{array}$ & 27 & 52.117 & 28 & 68 & 121 & 164 \\
\hline $\begin{array}{l}\text { Bushland/ } \\
\text { regrowth }\end{array}$ & 154197.54 & 17 & $\begin{array}{c}2.205 \\
( \pm 6.120)\end{array}$ & 3 & $\begin{array}{c}1.943 \\
( \pm 1.281)\end{array}$ & 2 & $\begin{array}{c}4.626 \\
( \pm 8.327)\end{array}$ & 3 & 10.794 & 6 & -12 & 110 & 390 \\
\hline $\begin{array}{l}\text { Grassland/ } \\
\text { fern }\end{array}$ & 154108.55 & 17 & $\begin{array}{c}0.394 \\
( \pm 2.478)\end{array}$ & 0 & $\begin{array}{c}0.515 \\
( \pm 1.600)\end{array}$ & 0 & $\begin{array}{c}1.849 \\
( \pm 2.075)\end{array}$ & 1 & 0.955 & 1 & 31 & 370 & 143 \\
\hline Burned & 65425.08 & 7 & $\begin{array}{c}0.682 \\
( \pm 1.761)\end{array}$ & 1 & $\begin{array}{c}0.047 \\
( \pm 0.549)\end{array}$ & 0 & $\begin{array}{c}0.00 \\
( \pm 0.00)\end{array}$ & 0 & 0.00 & 0 & -93 & -100 & -100 \\
\hline Total & 911450.10 & 100 & $\begin{array}{c}78.918 \\
( \pm 127.752)\end{array}$ & 100 & $\begin{array}{c}113.115 \\
( \pm 83.841)\end{array}$ & 100 & $\begin{array}{c}159.725 \\
( \pm 220.134)\end{array}$ & 100 & 186.922 & 100 & 43 & 102 & 137 \\
\hline
\end{tabular}

in these inaccessible ecosystems. In combination with highresolution satellite imagery, airborne LiDAR could be a costeffective approach to derive more accurate regional maps on forest carbon densities (Asner et al., 2010). Furthermore the new approach presented here through using the $\mathrm{CH}$ and incorporating LiDAR point densities as weight has the capability to improve current estimates on AGB spatial variability across different forest types and degradation levels also in other tropical biomes and to assist the efforts in up-scaling LiDAR-derived AGB estimates to large-scale geographic areas.

There exists a considerable natural variability of AGB up to $140 \%$ within the same forest type due to varying environmental conditions. We conclude that AGB is lower in forests which grow in areas where the water table is permanently high (low pole peat swamp forest) (Page et al., 1999). For example, we found that in water-logged conditions the AGB is significantly lower than in drier locations. AGB reduction by logging dating back more than 10 years can still be assessed by LiDAR but not by multispectral satellite imagery available for that period in time.

The up-scaling of LiDAR AGB to a large area of 1 million ha (59\% peat swamp forest) was compared to the indirect methods based on the Landsat land cover map (see Sect. 2.5) and site-specific field inventory data, regional literature values, and IPCC default values (Table 2). We observed that these indirect methods overestimated AGB vy $46 \%, 102 \%$, and $137 \%$, respectively. If the whole area were completely deforested - a likely scenario for the near future - this would lead to an overestimation 63, 148 and 198 megatons of $\mathrm{CO}_{2}$, respectively (34, 81 and 108 megatons of $\mathrm{AGB}$; conversion factor from AGB to carbon 0.5; IPCC, 2006).

Especially for the carbon-rich tropical peat swamp forests, this finding is of high importance because this ecosystem is disappearing at an alarming rate due to the conversion to oil palm plantations established to meet the demands for biofuels. By converting peat swamp forests into biofuel plantations, more carbon will be released than it is saved by using biofuels (Dewi et al., 2009).

For REDD+ activities, default values or indirect approaches to determine AGB are not sufficiently reliable and lead to inaccurate carbon stock estimates and consequently to excessive carbon credits and compensation payments.

Acknowledgements. We would like to thank Suwido Limin and his team from CIMTROP for the logistic support during the field inventory and Sampang Gaman (CIMTROP) and Simon Husson (Orang Utan Tropical Peatland Project, OUTROP) for providing tree species lists. Further we would like to thank FORRSA (Forest Restoration and Rehabilitation in Southeast Asia) project of the EU-funded Asia Link programme for financially supporting the field trips to Indonesia. The LiDAR data set was acquired by Kalteng Consultants.

Edited by: P. Stoy

\section{References}

Adams, J. B., Smith, M. O., and Johnson, P. E.: Spectral mixture modeling: A new analysis of rock and soil types at the Viking Lander 1 site, J. Geophys. Res., 91, 8090-8112, 1986.

Anderson, J. A. R.: Ecosystems of the World 4b-Mires: Swamp, Bog, Fern and Moor, edited by: Gore, A. J. P., Elsevier, Amsterdam, The Netherlands, 181-199, 1983.

Asner, G. P., Hughes, R. F., Varga, TA, Knapp, D. E., and KennedyBowdoin, T.: Environmental and biotic controls over aboveground biomass throughout a tropical rain forest, Ecosystems, 12, 261-278, 2009a. 
Asner, G. P., Knapp, D. E., Balaji, A., and Paez-Acosta, G.: Automated mapping of tropical deforestation and forest degradation: CLASlite, J. Appl. Remote Sens., 3, 033543, doi:10.1117/1.3223675, 2009b.

Asner, G. P., Powell, G. V. N., Mascaro, J., Knapp, D. E., Clark, J. K., Jacobson, J., Kennedy-Bowdoin, T., Balaji, A., Paez-Acosta, G., Victoria, E., Secada, L., Valqui, M., and Hughes, R. F.: Highresolution forest carbon stocks and emissions in the Amazon, P. Natl. Acad. Sci. USA, 107, 16738-16742, 2010.

Assmus, E.: Extension of Stuttgart Contour Program to treating terrain break lines, In: Proceedings of the symposium of the ISP, Commision III, Stuttgart 2.-6.9.1974. DGK, Reihe B, Vol. 214, 171-178, 1975

Baccini, A., Goetz, S. J., Walker, W. S., Laporte, N. T., Sun, M., Sulla-Menashe, D., Hackler, J., Beck, P. S. A., Dubayah, R., Friedl, M. A., Samanta, S., and Houghton, R. A.: Estimated carbon dioxide emissions from tropical deforestation improved by carbon-density maps, Nature Clim. Change, 2, 182-185, doi:10.1038/nclimate1354, 2012.

Ballhorn, U., Siegert, F., Mason, M., and Limin, S.: Derivation of burn scar depths and estimation of carbon emissions with LIDAR in Indonesian peatlands, P. Natl. Acad. Sci. USA, 106, 21213 21218, 2009.

Breipohl, A.: Probabilistic Systems Analysis: An Introduction to Probabilistic Models, Decisions, and Applications of Random Processes, John Wiley \& Sons, 1970.

Chave, J., Andalo, C., Brown, S., Cairns, M. A., Chambers, J. Q., Eamus, D., Folster, H., Fromard, F., Higuchi, N., Kira, T., Lescure, J.-P., Nelson, B. W., Ogawa, H., Puig, H., Riera, B., and Yamakura, T.: Tree allometry and improved estimation of carbon stocks and balance in tropical forests, Oecologia, 145, 87-99, 2005.

Chudnoff, M.: Tropical Timbers of the World. Agriculture Handbook 607, US Department of Agriculture, Forest Service, Forest Products Laboratory, Madison, WI, USA, 1984.

Dewi, S., Khasanah, N., Rahayu, S., Ekadinata, A., and Van Noordwijk, M.: Carbon Footprint of Indonesian Palm Oil Production: a Pilot Study, World Agroforestry Centre (ICRAF), Bogor, Indonesia, 2009.

Drake, J. B., Dubayah, R. O., Clark, D. B., Knox, R. G., Blair, J. B., Hofton, M. A., Chazdon, R. L., Weishampel, J. F., and Prince, S. D.: Estimation of tropical forest structural characteristics using large-footprint lidar, Remote Sens. Environ., 79, 305-319, 2002.

Drake, J. B., Knox, R. G., Dubayah, R. O., Clark, D. B., Condit, R., Blair, J. B., and Hofton, M.: Above-ground biomass estimation in closed canopy Neotropical forests using lidar remote sensing: factors affecting the generality of relationships, Glob. Ecol. Biogeogr., 12, 147-159, 2003.

Englhart, S., Keuck, V., and Siegert, F.: Aboveground biomass retrieval in tropical forests - The potential of combined X- and L-band SAR data use, Remote Sens. Environ., 115, 1260-1271, 2011.

FAO: Estimating biomass and biomass change of tropical forests: A primer, Food and Agriculture Organization of the United Nations, Rome, Italy, FAO Forestry Paper 134, 1997.

FAO: Global Forest Resources Assessment 2005, Food and Agriculture Organization of the United Nations, Rome, Italy, FAO Forestry Paper 147, 2006.
Gibbs, H. K., Brown, S., Niles, J. O., and Foley, J. A.: Monitoring and estimating tropical forest carbon stocks: making REDD a reality, Environ. Res. Lett,. 2, 045023, doi:10.1088/17489326/2/4/045023, 2007.

Hansen, M. C., Stehman, S. V., Potapov, P. V., Arunarwati, B., Stolle, F., and Pittman, K.: Quantifying changes in the rates of forest clearing in Indonesia from 1990 to 2005 using remotely sensed data sets, Environ. Res. Lett., 4, 034001, doi:10.1088/1748-9326/4/3/034001, 2009.

Hooijer A, Page, S., Canadell, J. G., Silvius, M., Kwadijk, J., Wödten, H., and Jauhiainen, J.: Current and future $\mathrm{CO}_{2}$ emissions from drained peatlands in Southeast Asia, Biogeosciences, 7, 1505-1514, 2010, http://www.biogeosciences.net/7/1505/2010/.

IPCC: Guidelines for National Greenhouse Gas Inventories, edited by: Eggleston, H. S., Buendia, L., Miwa, K., Ngara, T., and Tanabe, K., Japan, National Greenhouse Gas Inventories Programme, 2006

IPCC: Climate Change 2007: The Physical Science Basis. Contribution of Working Group I to the Fourth Assessment Report of the Intergovernmental Panel on Climate Change, edited by: Solomon, S., Qin, D., Manning, M., Chen, Z., Marquis, M., Averyt, K. B., M. Tignor, M., and Miller, H. L., Cambridge University Press, Cambridge, United Kingdom, 2007.

Jaenicke J., Englhart, S., and Siegert, F.: Monitoring the effect of restoration measures in Indonesian peatlands by radar satellite imagery, J. Environ. Manage., 92, 630-638, 2011.

Kraus, K.: Interpolation nach kleinsten Quadraten versus KriegeSchätzer, Österreichische Zeitschrift für Vermessung und Geoinformation, 86, 45-48, 1998.

Langner, A., Miettinen, J., and Siegert, F.: Land cover change 2002 2005 in Borneo and the role of fire derived from MODIS imagery, Glob. Change Biol., 13, 1-12, 2007.

Langner, A. and Siegert, F.: Spatiotemporal fire occurence in Borneo over a period of 10 years, Glob. Change Biol., 15, 48-62, 2009.

Lefsky, M. A., Harding, D. J., Cohen W. B., Parker, G. G., and Shugart, H. H.: Surface Lidar Remote Sensing of Basal Area and Biomass in Deciduous Forests of Eastern Maryland, USA, Remote Sensing of Environment, 67, 83-98, 1999.

Lefsky, M. A., Cohen, W. B., Harding, D. J., Parker, G. G., Acker, S. A., and Gower, S. T.: Lidar remote sensing of above-ground biomass in three biomes, Global Ecol. Biogeogr., 11, 393-399, 2002.

Lefsky, M. A., Harding, D. J., Keller, M., Cohen, W. B., Carabajal, C. C., Espirito-Santo, F. D. B., Hunter, M. O., and De Oliveira Jr., R.: Estimates of forest canopy height and aboveground biomass using ICESat, Geophys. Res. Lett., 32, L22S02, 2005.

Matricardi, E. A. T., Skole, D. L., Pedlowski, M. A., Chomentowski, W., and Fernandes, L. C.: Assessment of tropical forest degradation by selective logging and fire using Landsat imagery. Remote Sens. Environ. 114:1117-1129, 2010.

Means, J. E., Acker, S. A., Harding, D. J., Blair, J. B., Lefsky, M. A., Cohen, W. B., Harmon, M. E., and McKee, W. A.: Use of large-footprint scanning airborne lidar to estimate forest stand characteristics in the Western Cascades of Oregon, Remote Sens. Environ., 67, 298-308, 1999.

Page, S. E. and Rieley, J. O.: Tropical peatlands: A review of their natural resource functions with particular reference to Southeast 
Asia, Int. Peat J., 8, 95-106, 1998.

Page, S. E., Rieley, J. O., Shotyk, W., and Weiss, D.: Interdependence of peat and vegetation in a tropical peat swamp forest, Philos. Trans. R. Soc. Lond., 354, 1885-1897, 1999.

Page, S. E., Siegert, F., Rieley, J. O., Boehm, H.-D., V., Jaya, A., and Limin, S.: The amount of carbon released from peat and forest fires in Indonesia during 1997, Nature, 420, 61-65, 2002.

Page, S. E., Wüst, R. A. J., Weiss, D., Rieley, J. O., Shotyk, W., and Limin, S. H.: Late Pleistocene and Holocene carbon accumulation and climate change from an equatorial peat bog (Kalimantan, Indonesia): Implications for past, present and future carbon dynamics, J. Quat. Sci., 19, 625-635, 2004.

Page, S. E., Rieley, J. O., and Banks, C. J.: Global and regional importance of the tropical peatland carbon pool, Glob. Chang. Biol., 17, 798-818, 2010.

Pearson, T., Walker, S., and Brown, S.: Sourcebook for Land Use, Land-Use Change and Forestry Projects, Winrock International, Little Rock, AR, USA, 2005.

Pfeifer, N., Stadler, P., and Briese, C.: Derivation of digital terrain models in SCOP++ environment, in: OEEPE Workshop on Airborne Laserscanning and Interferometric SAR for Detailed Digital Elevation Models, Stockholm, 2001.

Popescu, S. C.: Estimating biomass of individual pine trees using airborne lidar, Biomass and Energy, 31, 646-655, 2007.

Putz, F. E. and Romero, C.: Helping curb tropical forest degradation by linking REDD+ with other conservation interventions: A view from the forest, Current Opinion in Environmental Sustainability, 4, 670-677, 2012.

Rieley, J. O., Ahmad-Shah, A. A., and Brady, M. A.: The extent and nature of tropical peat swamps, In: Tropical Lowland Peatlands of Southeast Asia: Proceedings of a Workshop on Integrated Planning and Management of Tropical Lowland Peatlands held at Cisarua, Indonesia, 3-8 July 1992, edited by: Maltby, E., Immirzi, C. P., and Safford, R. J., IUCN, Gland, Switzerland, 17-53, 1996.

Richter, R.: Correction of atmospheric and topographic effects for high spatial resolution imagery, Int. J. Remote Sens., 8, 10991111, 1997.
Rieley, J. O. and Page, S. E.: Wise Use of Tropical Peatlands: Focus on Southeast Asia, edited by: Rieley, J. O., and Page, S. E., ALTERRA, Wageningen, Netherlands, 2005.

Rosenqvist, A., Milne, A., Lucas, R., Imhoff, M., and Dobson, C.: A review of remote sensing technology in support of the Kyoto Protocol, Environ. Sci. Policy, 6, 441-455, 2003.

Ryan, C. M., Hill, T., Woollen, E., Ghee, C., Mitchard, E., Cassells, G., Grace, J., Woodhouse, I. H., and Williams, M.: Quantifying small-scale deforestation and forest degradation in African woodlands using radar imagery, Glob. Chang. Biol., 18, 243257, 2012.

Saatchi, S. S., Harris, N. L., Brown, S., Lefsky, M., Mitchard, E. T. A., Salas, W., Zutta, B. R., Buermann, W., Lewis, S. L., Hagen, S., Petrova, S., White, L., Silman, M., and Morel, A.: Benchmark map of forest carbon stocks in tropical regions across three continents, P. Natl. Acad. Sci., 108, 9899-9904, 2011.

Siegert, F., Rücker, G., Hinrichs, A., and Hoffmann, A.: Increased fire impacts in logged over forests during El Niño driven fires, Nature, 414, 437-440, 2001.

Sorensen, K. W.: Indonesian peat swamp forests and their role as a carbon sink, Chemosphere, 27, 1065-1082, 1993.

Souza, C. M., Roberts, D. A. Jr, and Cochrane, M. A.: Combining spectral and spatial information to map canopy damage from selective logging and forest fires, Remote Sens. Environ., 98, 329343, 2005.

Van der Werf, G. R., Morton, D. C., DeFries, R. S., Olivier, J. G. J., Kasibhatla, P. S., Jackson, R. B., Collatz, G. J., and Randerson, J. T.: $\mathrm{CO}_{2}$ emissions from forest loss, Nat. Geosci., 2, 737-738, 2009.

Wild, E.: Die Prädiktion mit Gewichtsfunktionen und deren Anwendung zur Beschreibung von Geländeflächen bei topographischen Geländeaufnahmen, in: DGK, Reihe C, Vol. 277, Dissertation at the University Stuttgart, 1983.

Zhao, K. G., Popescu, S., and Nelson, R.: Lidar remote sensing of forest biomass: A scale-invariant estimation approach using airborne lasers, Remote Sens. Environ., 113, 182-196, 2009. 